This PDF is a selection from a published volume from the National Bureau of Economic Research

Volume Title: Labor Markets and Firm Benefit Policies in Japan and the United States

Volume Author/Editor: Seiritsu Ogura, Toshiaki Tachibanaki and David A. Wise, editors

Volume Publisher: University of Chicago Press

Volume ISBN: 0-226-62094-8

Volume URL: http://www.nber.org/books/ogura03-1

Conference Date: January 20-23, 2000

Publication Date: January 2003

Title: Option Value Estimation with Health and Retirement Study Data

Author: Andrew Samwick, David A. Wise

URL: http://www.nber.org/chapters/c10308 


\section{Option Value Estimation with Health and Retirement Study Data}

Andrew Samwick and David A. Wise

\subsection{Introduction}

The relationship between retirement and the provisions of Social Security and employer-provided pension plans has been widely studied, and analyses have been based on many different methods. Recently, considerable work has been based on the "option value" model developed by Stock and Wise (1990a,b). In this paper, we move toward an option value analysis based on data from the new Health and Retirement Study (HRS).

Both public and private retirement benefits often accrue unevenly, with large jumps in benefit entitlement for working an additional year at some ages, small increases at other ages, and very often a loss in benefits for working beyond certain ages. Employer-provided defined benefit plans in the United States provide a good example. ${ }^{1}$ Specific provisions vary widely across firms so that the accrual patterns also vary greatly as well. Thus, to study the effects of plan provisions on retirement it is critical to know the

Andrew Samwick is professor of economics at Dartmouth College and a research associate of the National Bureau of Economic Research. David A. Wise is the John F. Stambaugh Professor of Political Economy at the John F. Kennedy School of Government, Harvard University, and the director for health and retirement programs at the National Bureau of Economic Research.

We are grateful to the National Institute on Aging for financial support and to Bob Peticolas for assistance with the pension provider software and data. We thank Yukiko Abe, Alan Gustman, and participants at the joint Japan Center for Economic Research-National Bureau of Economic Research conference on "Labor Markets and Firm Benefit Policies in Japan and the United States" for helpful comments. Any errors are our own.

1. The strong relationship between retirement plan provisions and retirement is not limited to defined benefit pension plans in the United States. The striking relationship between public retirement plans and labor force departure rates in many countries is described in a coordinated collection of country analyses. The results in eleven countries are summarized by Gruber and Wise (1998). 
precise provisions of the plan that determine a person's benefits. In addition, benefits under defined benefit plans are typically determined by past wage rates. Although some surveys have obtained earnings histories, until the advent of the HRS, plan provisions have not been available in surveys that obtain information on retirement.

The incentive effects inherent in plan provisions were first described by Bulow (1981) and emphasized by Lazear (1983). Kotlikoff and Wise (1985, 1987, 1989b) used data from the Bureau of Labor Statistics - which provided information on the precise provisions of a large sample of employerprovided plans - to describe the incentive effects over a broad range of plans and emphasized the enormous variation across plans. These data, however, contained no information on the retirement decisions of individuals covered by the plans. To obtain plan provisions together with retirement data, they turned their attention to firm personnel records. These data included information on individuals' retirement decisions as well as information on their earnings histories, in addition to a precise description of their firm pension plan provisions. Kotlikoff and Wise (1989a) used such data to describe the striking relationship between pension plan provisions in a firm and retirement from that firm.

These firm data were then used by Stock and Wise (1990a,b) in the development and estimation of the option value model. The central feature of this method is recognition of the future accrual pattern of pension benefits. Subsequent analyses by Lumsdaine, Stock, and Wise (1992) of the option value model in comparison with a stochastic dynamic programming specification were based on additional firm data. Several additional papers by Lumsdaine, Stock, and Wise $(1990,1991,1993)$ compared results from several different firms, for men and women, and for different types of employees. The substantial similarity of parameter estimates across different firms and for different groups of employees suggested a rather strong behavioral interpretation of the model estimates. This was confirmed through external "out-of-sample" checks of predictive validity, by considering how well the model predicted the effect on retirement of unanticipated and temporary changes in pension plan provisions, occasioned by early retirement window plans. Such tests were emphasized by Lumsdaine, Stock, and Wise (1990, 1991, 1992). The option value model was also used by Ausink (1991) and Ausink and Wise (1996) to explain retirement from the U.S. Air Force.

This series of analyses demonstrated the very strong pension plan incentives to retire and actual firm departures. The firm data, however, typically provide individual data only on information used to calculate pension benefits - earnings history, age, and years of service - and limited demographic data, like gender and sometimes worker type (e.g., salaried or hourly wage, white-collar versus production). Other individual attributes that are likely to affect retirement are not available in firm personnel record 
files. There is no measure of health status, for example. Nor is there information on nonpension assets. Additionally, the particular firms from which the personnel records are obtained are not necessarily representative of the entire population of workers covered by pensions.

Samwick (1998) made the first attempt to integrate all of these individual attributes into an option value analysis, using data from the 1983 Survey of Consumer Finances (SCF). The SCF 1983 was the first nationally representative data set to contain a companion Pension Provider Survey (PPS) of several hundred plans. Using parameters from the Stock and Wise (1990b) literature, he showed that a calculated option value of continued work was a significant predictor of retirement and performed better in estimation and simulation than a simpler one-year retirement wealth accrual. The results extended and generalized the results of two previous literatures: estimates of the effect of Social Security that failed to account for pensions, and option value estimates of the effect of pensions on firm-level, rather than population, data. However, there were several shortcomings of the analysis, including a small sample size, a limited panel dimension, and the lack of comprehensive wage histories.

A central goal of the HRS was to obtain information on individual attributes that would be likely to affect retirement in conjunction with precise descriptions of the provisions of pension plans under which employees were entitled to benefits. The HRS combines a PPS with detailed wage histories and has been conducted every other year since 1992. It therefore provides new opportunities to examine retirement in a very comprehensive setting. Coile and Gruber (2000, 2001), Coile (1999), and Harris (2001) have recently estimated variants of the option value model using HRS data.

In this paper, we describe initial exploratory work that will lead to an option value analysis based on the HRS data. There are three goals. The first is to describe the critical content of the HRS and confirm that these new data are important components of comprehensive analysis of retirement. The second is to make preliminary calculations of pension incentives and to estimate their effect on the probability of retirement. We choose a reduced-form framework that allows nonpension characteristics to be easily incorporated. The third goal, by way of the first two, is to provide guidance that we hope will help analysts in other countries who may wish to conduct such analyses and indeed may wish to develop HRS-like surveys.

\subsection{Descriptive Data}

In this section, we begin by describing the important features of the HRS that facilitate analyses of retirement. The first is the self-reported information on pension plans and expected entitlements. Pensions are organized as defined benefit (DB), in which future benefits paid by the employer are 
based on a set of formulas that depend on age, years of service, and earnings levels, or as defined contribution (DC), in which employers and sometimes employees make specified contributions to an account that accumulates until the employee leaves the firm. Employees may be covered by a DB plan, a DC plan, or both. Employees without pensions of any kind are covered only by Social Security. A second feature is health status. The HRS contains several different measures of health status, including information on important changes in health between survey waves. There is also information on health insurance coverage, for both workers and retirees. The third feature is wealth other than pensions, which may also be an important determinant of retirement, especially as it interacts with health and the availability of pensions immediately upon retirement. A fourth feature is the definition of retirement. The effect of pensions on the decision to leave a particular firm differs substantially from their effect on the decision to leave the labor force entirely. Depending on the context, either of these decisions could be the appropriate definition of retirement.

The HRS sample includes people between the ages of fifty-one and sixtyone who are at many different stages of their working careers. Table 8.1 gives a breakdown of the sample by labor force status and gender. The sample includes all age-eligible respondents for whom wealth and selfreported pension data are available in wave 1 and whose labor force status could be obtained in wave 2. The top two rows show that 70.17 percent of the sample is working, with 57.01 percent employed and 13.16 percent selfemployed. Since pensions are disproportionately a phenomenon of employees, our subsequent analysis will focus on this group. Employment probabilities differ by gender, with 80.16 percent of men and 61.16 percent

Labor Force Status of Health and Retirement Study in Wave 1

\begin{tabular}{lrrr}
\hline & Men & Women & Total \\
\hline Working & & & \\
Employed & 61.59 & 52.87 & 57.01 \\
Self-employed & 18.57 & 8.29 & 13.16 \\
Not working & & & \\
Unemployed & 3.69 & 2.75 & 3.20 \\
Laid off & 0.32 & 0.34 & 0.33 \\
Disabled & 8.60 & 8.11 & 8.34 \\
Retired & 6.89 & 5.88 & 6.36 \\
Homemaker & 0.06 & 20.87 & 11.01 \\
Other & 0.29 & 0.88 & 0.60 \\
$N \quad$ & 4,026 & 4,466 & 8,492 \\
\hline
\end{tabular}

Notes: Each cell contains the percent of each column in the specified labor force status group. Percentages are weighted by person-level weights. The sample includes all age-eligible respondents to the HRS Wave 1 for whom wealth and self-reported pension data are available in Wave 1 and whose labor force status could be obtained in Wave 2. 
of women working. About 10 percentage points of this disparity are due to self-employment, with the remaining 8.72 percentage points due to employment.

The rest of the table describes the subsample that is not working. For men, about 8.60 percent report that they are disabled, with another 6.89 percent retired and 4.01 percent unemployed or laid off. For women, the corresponding percentages are lower by up to 1 percentage point in each of these categories. The final categories, "homemakers" and "other" responses, comprise 21.75 percent of the sample of women and a negligible proportion of the sample of men.

Table 8.2 provides a breakdown of the working sample based on selfreported pension coverage. We distinguish four groups (excluding the very small number of workers who did not report the type of pension plan they had): no pension, DC only, DB only, and both DB and DC. The first row of the table shows that approximately one-third of the sample is not covered by an employer-provided pension plan. Employers are under no obligation to offer pension plans to their workers, although there are many regulations that require employers not discriminate among classes of workers if they sponsor a plan for any of their workers. The coverage rates differ by gender, with women having a 40 percent chance of not being covered compared to 28 percent for men. This group of workers depends on Social Security for much of their retirement income. The incentive effects of Social Security on retirement are similar to those of DB pensions, described presently. A recent exposition using HRS data can be found in Coile and Gruber (2001).

As previously noted, there are two primary types of pension plans. A DC plan is organized as a fund into which the employer and employee may make contributions. The contributions are invested, often with employee discretion, and accumulated until the employee leaves the firm. At that time, the employee can generally take the benefits as a lump sum, an annu-

Pension Coverage of Employed Workers in HRS Wave 1

\begin{tabular}{lccc}
\hline & Men & Women & Total \\
\hline No pension & 27.87 & 39.91 & 33.74 \\
DC pension only & 20.11 & 20.19 & 20.15 \\
DB pension only & 29.09 & 26.45 & 27.80 \\
DB and DC pensions & 22.93 & 13.46 & 18.31 \\
$N$ & 2,450 & 2,334 & 4,784 \\
\hline
\end{tabular}

Notes: Each cell contains the percent of each column with the specified type of pension. Percentages are weighted by person-level weights. The sample includes all age-eligible respondents to the HRS Wave 1 for whom wealth and self-reported pension data are available in Wave 1 and whose labor force status could be obtained in Wave 2. Only respondents who are working but not self-employed are included. 
ity, or as a rollover into another retirement account. In general, DC pensions do not have important incentive effects regarding the timing of retirement. Their main incentive effects typically occur early in the employee's tenure, as vesting provisions encourage employees to stay with the firm for a specified period of time in order to receive their employers' contributions. The next row of the table shows that roughly 20 percent of both men and women in the HRS are covered only by DC pensions.

A DB plan is organized around one or more formulas that specify a benefit payment as a function of the employee's retirement age, years of participation in the plan, and earnings while covered by the plan. The benefits from a DB plan are usually paid as an annuity. The benefit levels may change over time due to cost-of-living adjustments (formally through the plan provisions or informally through the employer's discretionary increases). Benefit formulas are often integrated with Social Security benefit levels or early and normal retirement ages. The next two rows of the table show that 29.09 percent of men are covered only by a DB plan, with another 22.93 covered by a plan with features of both a DB and a DC plan or by at least one plan of each type. Over half of male workers are therefore covered by a plan with DB characteristics. For women, approximately 40 percent have a plan with DB characteristics, with 26.45 percent having a DB only and 13.46 having both types of plan.

The critical feature of DB plans for the study of retirement behavior is the very strong incentives they provide to workers to retire at specific ages. Two factors are generally at work in providing incentives to stay with the firm. The first is that when final pay is computed, earnings are typically specified in nominal amounts. Thus, an extra year of work indexes the initial benefit to nominal wage growth. This is very important early in the career, when nominal wage growth is high, and less important later in the career, when wage growth is less rapid. The second is the actuarial reduction factor applied to initial benefit ages that are less than the plan's normal retirement age (NRA). The NRA is the age at which the worker is entitled to the full amount of the benefits implied by the appropriate pension formula. If the worker leaves before the early retirement age (ERA), then benefits are usually payable at the ERA with a full actuarial reduction for each year of extra benefit receipt relative to the NRA. If the worker stays until he or she qualifies for early retirement benefits, then the reduction factor is typically more advantageous than an actuarially fair rate. Such features provide a strong incentive to stay with the firm at least until the ERA. In contrast, benefits are not as generously increased for delaying initial receipt of benefits beyond the NRA - the upward revision is often less than actuarially fair.

These incentives can be easily quantified by considering the financial incentives to delay retirement by a single year. We compute this "pension wealth accrual" as the difference in the actuarial present value of the pay- 


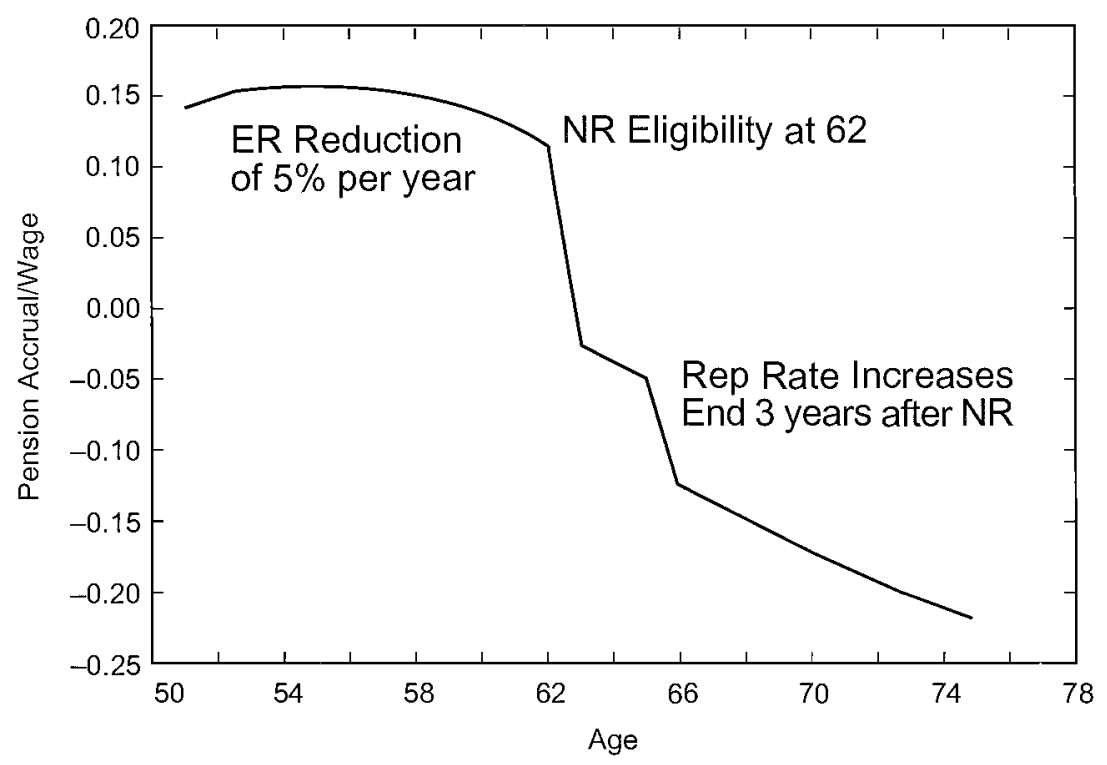

Fig. 8.1 Pension accrual profile, for worker hired at age 40

ments from the pension if retirement occurred next year instead of this year. Figure 8.1 graphs the pension wealth accrual for a hypothetical worker in a large plan in the HRS sample. The plan's normal retirement age is sixty-two, but all workers with ten years of work at the firm qualify for early retirement at a favorable reduction rate. Alternatively, workers can qualify for normal retirement as soon as they have worked thirty years at the firm. Benefits are equal to 1.6 percent of final average pay-defined as the average of the last five years of wages - for every year worked. Workers can increase this percentage slightly by working up to three years after first qualifying for normal retirement benefits. The graph depicts the ratio of the pension accrual to the wage for a hypothetical worker who was hired at age forty. The vertical height of each point on the graph is the pension accrual received by working to that age instead of leaving at the previous age.

The idiosyncrasies of the plan's benefit and eligibility formulas are reflected in the shape of the graph. Since the worker was hired at forty, she will qualify for normal retirement benefits at age sixty-two. In years prior to that, the pension accrual is at approximately 15 percent of the contemporaneous wage. This amount is quite substantial on an annual basis, and it is by no means atypical of DB plans. It reflects the extra year of earnings, the additional year closer to the NRA, and the higher level of final average pay. At the NRA of sixty-two, there are no more increments for reaching the NRA, so the accrual falls to zero and then below. For the next three years, accruals stay above -10 percent. After the replacement rate adjust- 


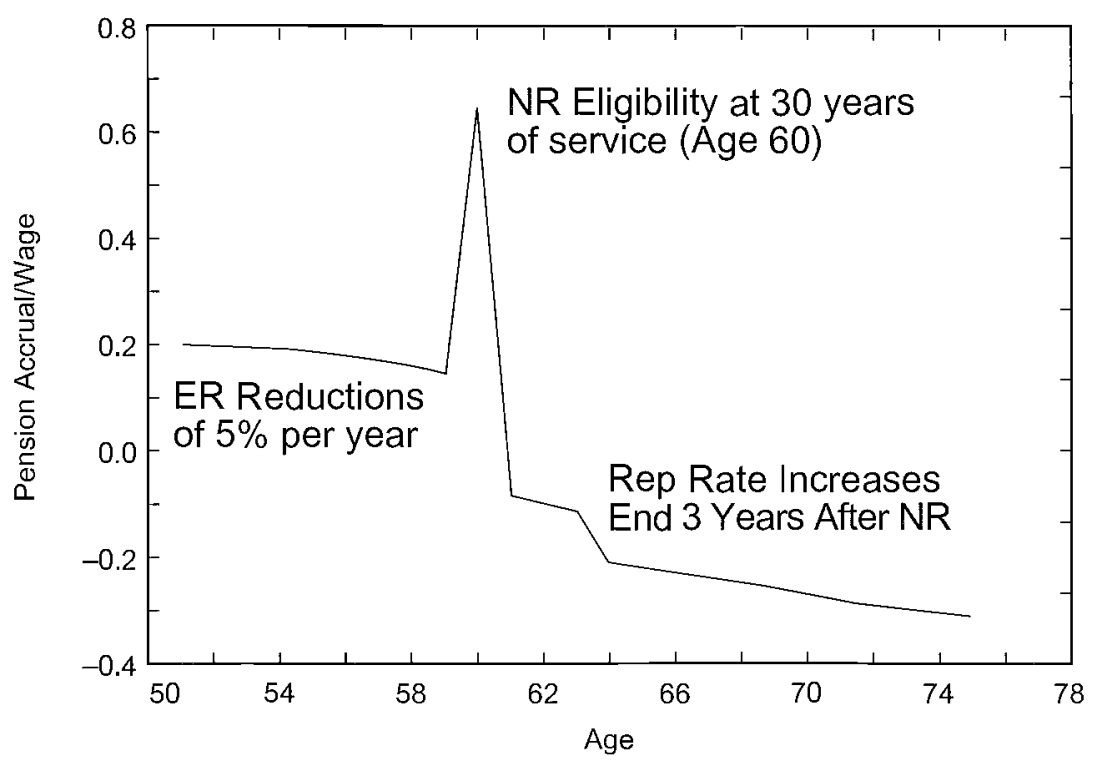

Fig. 8.2 Pension accrual profile, for worker hired at age 30

ments stop, the pension accrual is quite negative, as the worker is simply giving up additional years of benefits with little upward revision to the benefit amount. In such a graph, positive values reflect a financial incentive to stay at the firm, and negative values provide a financial incentive to leave the firm.

As an illustration of the sensitivity of pension accrual calculations to age and years of work, figure 8.2 shows the pension accrual for the same worker, assuming she was hired at age thirty rather than age forty. The main change in the profile is that the worker reaches thirty years of service at age sixty and can retire with full benefits at that time. Prior to that age, accruals are approximately 20 percent of the contemporaneous wage. At that age, the present value of the two fewer years worth of benefit reductions due to early retirement generates a considerable spike in the profile, equal to about 70 percent of earnings that year. ${ }^{2}$ The accruals then turn negative, particularly after the three years of replacement rate increases are exhausted. Clearly, if this worker is observed to retire at age fifty-nine, right before this spike, then we would reasonably conclude that financial incentives can have little to do with retirement decisions.

Several conclusions can be drawn from these graphs. The first is that

2. Large pension accruals are also common at the earliest possible ERA, due to the sudden switch to an actuarially favorable reduction rate for benefits taken before the NRA. In this plan, the ERA occurs ten years after hire. A worker hired at age forty-six would have a large accrual at age fifty-six under this plan. 
there is considerable heterogeneity in the financial incentives from pension plans. These incentives will vary across plans and, importantly, across workers in the same plan based on age and years of service. The second is that the types of incentives provided by DB pension plans may change over a worker's career. At younger ages, the prospect of large accruals for continued work provides financial incentives to delay retirement until the early retirement age. After the early retirement age, benefit adjustments for continued work are typically not enough to compensate for the lost year of benefit receipt, and the pension incentives encourage departure from the firm. Social Security and pension formulas may differ in which type of incentive is more pronounced. The third conclusion is that the data requirements to calculate pension accruals are considerable and exacting. Missing the date of birth by a year could place the large spike at sixty-one instead of sixty. We might observe a worker stay through age sixty and then retire. If we have missed the date by only a year, then this worker will retire after actually getting the large increment to wealth but appear to retire just before it. The problem is even more severe when the possible mistakes pertain to the date of hire. In the original Stock and Wise (1990b) literature, personnel records from a handful of firms could identify this date precisely. In a household survey, even with Social Security earnings histories, mismeasurement is more likely to be a source of noise.

We distinguish two different stages of retirement between the first two waves of the HRS. We denote "full retirement" as a transition in labor force status from working to retirement, as indicated by the individual. However, the payment of pension benefits is conditional not on complete withdrawal from the labor force but only on separation from the employer. We denote "firm retirement" as any departure from the employer indicated in the first wave of the survey, regardless of what the worker did after that. The option value literature, because it utilizes personnel records, is generally constrained to analyzing only firm retirement. Samwick's (1998) analysis considers both definitions of retirement and finds a significant effect of the calculated option value in both cases. ${ }^{3}$

Figure 8.3 shows the hazard rate for full retirement between the first two waves of the HRS. The hazard rate is the probability of retiring at a given age, conditional on not having retired before that age. ${ }^{4}$ The graph contains separate hazard rates for each of the four pension coverage groups identified in table 8.2. As there are approximately two years between the waves of the HRS, the probabilities in the table reflect the probability of retiring at any point during that time interval. In general, there is an upward-sloping pattern to the retirement hazards, indicating a strong effect of age on re-

3. See Ruhm (1990) for an analysis of partial retirement and the role of "bridge" jobs.

4. It is important to note that in what follows we are examining retirement probabilities for those who are working in the first wave. This ignores the contribution of those who have already retired before the first wave on the calculation of the hazard rate. 

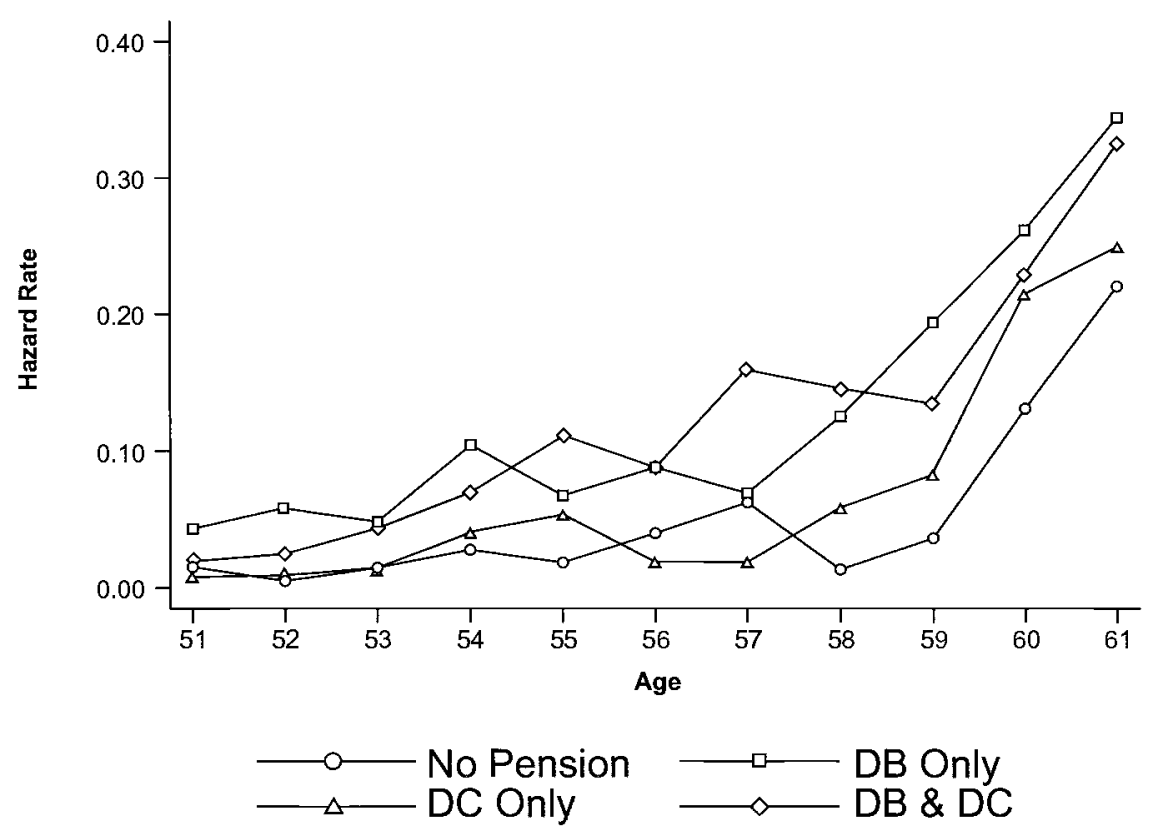

Fig. 8.3 Full retirement hazards, by pension type

tirement. The particularly large increases for ages sixty and sixty-one are due to the ERA for Social Security of sixty-two. Although the level of the hazards is comparable across the four groups, workers without pensions tend to have the lowest retirement probabilities, and those with DB or DB and DC pension tend to have the highest probabilities. There are noticeable upturns in the DB pension groups at ages fifty-four and fifty-five, owing to the ERA of fifty-five in many plans.

Figure 8.4 shows the analogous graph for firm retirement. The striking feature of this graph is the very high departure rate for workers without pensions. At all ages, approximately 40 percent of the workers without pensions leave their employers during the two years between the first two waves of the HRS. Because the level of this graph differs substantially from the full retirement hazard, we can infer that most of the departures result in a job at a different employer or any of the other nonretirement categories of labor force status shown in table 8.1. The hazard rates for workers with pensions do not approach 40 percent until the ages immediately prior to sixty-two. Hazard rates for workers with pensions show the same increasing pattern as in the full retirement graph.

There are two likely explanations for the higher hazard rates for workers without pensions. The first is that jobs that offer pensions are simply better jobs than jobs without pensions. In that case, workers are generally 

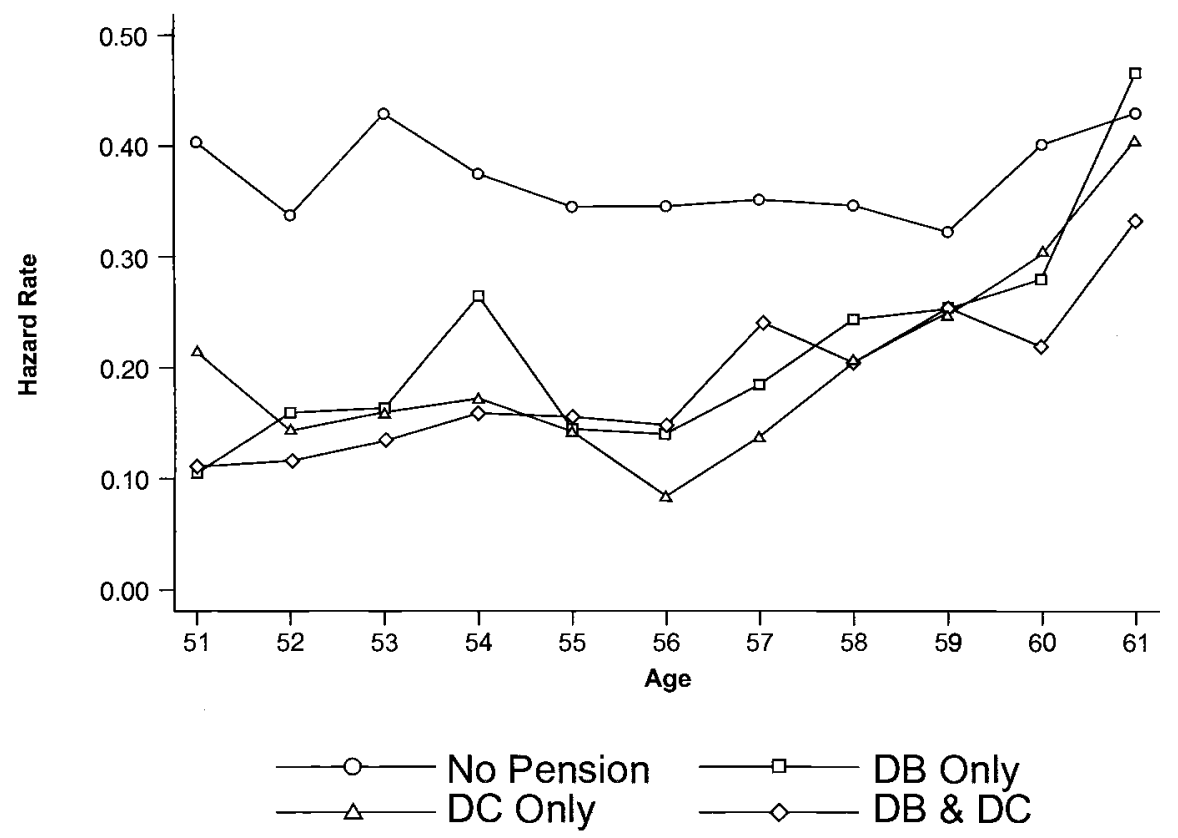

Fig. 8.4 Firm retirement hazards, by pension type

happier with their employers and, for that reason, less inclined to leave. This type of unobserved heterogeneity is not present in option value models based on a single firm, in which all workers have the same job and the same pension. The second explanation is based on the fact that most of the strong pension incentives are to delay retirement at these ages. As a result, we should see lower retirement probabilities when workers have pensions. The pension signals the likelihood of a large accrual of wealth at some point in the future with continued work.

In either case, the impact on a cross-sectional retirement model is clear. Since accruals are positive on average, variation in financial incentives between pension-covered and uncovered workers introduces a negative correlation between accruals and retirement, even if it were the case that among workers with pensions, higher accruals have no effect on the timing of retirement. As a precaution against this possibility, we condition on pension coverage in the tabulations in the remainder of this section and examine only workers with pensions in the econometric estimates in the next section.

The purpose of pensions is to provide resources to support consumption in retirement. Workers can also provide these resources by saving on their own. Other things being equal, workers with more wealth may choose to retire earlier. This could be true for exogenous reasons, such as receiving 
Table 8.3

Full Retirement Probabilities by Wealth and Pension Type

\begin{tabular}{lccccc}
\hline & Bottom Quartile & 2nd Quartile & 3rd Quartile & Top Quartile & All Quartiles \\
\hline Net worth & & & & & \\
$\quad$ No pension & 2.7 & 6.5 & 4.5 & 7.8 & 5.0 \\
DC only & 1.7 & 4.7 & 7.2 & 9.4 & 5.9 \\
DB only & 7.6 & 7.8 & 11.4 & 18.9 & 11.5 \\
DB and DC & 4.0 & 8.7 & 10.8 & 13.5 & 10.5 \\
All types & 3.8 & 6.9 & 8.5 & 12.7 & 8.0 \\
Financial assets & & & & & \\
No pension & 2.5 & 5.5 & 4.4 & 9.7 & 5.0 \\
DC only & 3.0 & 4.5 & 6.5 & 9.2 & 5.9 \\
DB only & 4.8 & 8.9 & 15.1 & 16.7 & 11.5 \\
DB and DC & 5.4 & 6.0 & 7.4 & 17.3 & 10.5 \\
All types & 3.3 & 6.4 & 8.6 & 17.9 & 8.0 \\
\hline
\end{tabular}

Notes: Each cell contains the probability that the employee retired from the labor force (full retirement) between the first two waves of the HRS. Probabilities are weighted by person-level weights. The sample includes all age-eligible respondents to the HRS Wave 1 for whom wealth and self-reported pension data are available in Wave 1 and whose labor force status could be obtained in Wave 2. Only respondents who are working but not self-employed are included.

an inheritance. It may also be true for endogenous reasons - workers who have a strong preference for consuming resources during retirement will save more while working to facilitate an earlier retirement date. ${ }^{5}$ As a first step, we tabulate the probability of retirement for workers in the four quartiles of the wealth distribution, controlling for pension coverage. We make separate calculations for total household net worth and financial assets. The quartiles for the net worth distribution are $\$ 42,500, \$ 111,540$, and $\$ 224,150$. Financial assets include liquid assets such as bank and money market accounts, certificates of deposit, stocks, bonds, mutual funds, and individual retirement accounts (IRAs). The quartiles of the financial asset distribution are $\$ 2,500, \$ 18,500$, and $\$ 62,000$.

Table 8.3 presents the results for full retirement. The bottom row of the top panel shows that retirement probabilities increase with the level of wealth, with the largest increase coming for the top quartile of the distribution. The other rows in that panel show that this holds true in each of the pension groups as well. The bottom panel of the table shows that the same qualitative results hold for the quartiles of the financial asset distribution as well.

The analogous calculations for firm retirement are presented in table 8.4. There are several interesting patterns in the relationship between wealth and retirement. First, for the whole sample of workers, firm retirement probabilities are highest for the top and bottom quartiles than in the

5. See Gustman and Steinmeier (1999) for a recent study of retirement saving using the HRS. 
Firm Retirement Probabilities by Wealth and Pension Type

\begin{tabular}{lccccc}
\hline & Bottom Quartile & 2nd Quartile & 3rd Quartile & Top Quartile & All Quartiles \\
\hline Net worth & & & & & \\
$\quad$ No pension & 39.5 & 34.1 & 33.9 & 38.9 & 37.0 \\
DC only & 14.1 & 15.9 & 20.5 & 25.3 & 19.1 \\
DB only & 19.2 & 18.3 & 18.7 & 26.6 & 20.7 \\
DB and DC & 22.1 & 14.7 & 18.2 & 16.9 & 17.4 \\
All types & 28.8 & 22.3 & 22.9 & 27.2 & 25.3 \\
Financial assets & & & & & \\
$\quad$ No pension & 39.2 & 36.8 & 31.2 & 39.3 & 37.0 \\
DC only & 14.3 & 18.7 & 18.1 & 24.7 & 19.1 \\
DB only & 18.8 & 17.0 & 22.8 & 24.6 & 20.7 \\
DB and DC & 18.0 & 13.9 & 17.5 & 19.6 & 17.4 \\
All types & 28.1 & 23.1 & 22.9 & 27.1 & 25.3 \\
\hline
\end{tabular}

Notes: Each cell contains the probability that the employee left the Wave 1 employer (firm retirement) between the first two waves of the HRS. Probabilities are weighted by person-level weights. The sample includes all age-eligible respondents to the HRS Wave 1 for whom wealth and self-reported pension data are available in Wave 1 and whose labor force status could be obtained in Wave 2. Only respondents who are working but not self-employed are included.

middle two quartiles. This is largely due to the presence of this pattern in the set of workers without pensions. Second, for the subsample of workers with DC only or DB only pensions, firm retirement probabilities are much higher for the top wealth quartile than for lower quartiles. This is the same pattern from the full retirement probabilities in table 8.3. Third, for workers with DB and DC pensions, workers in the 2nd quartile of the distribution have unusually low firm retirement probabilities. Wealth is clearly an important factor to incorporate into the analysis of retirement.

An important feature of the HRS is the thorough information that is provided on respondents' health and their resources available in the event of the onset of failing health. Studies have already been conducted using the data on important changes in health between surveys. In our preliminary investigations, we focus on self-reported health status and the availability of health insurance both while working and during retirement.

Table 8.5 breaks down the probability of retirement by the interaction of health status and various health insurance characteristics. The top row shows the fraction of the sample that reports each of the five possible answers. Only 2 percent report poor health. This very select group of workers has the highest rate of firm retirement and the lowest rate of full retirement. This holds true for almost all of the insurance categories. These workers tend to leave by way of disability, and such transitions are not included in our measure of self-reported full retirement status. Another 9.3 percent of the sample reports fair health, and the remainder of the sample is split into excellent (27.7 percent), very good (33.3 percent), or good (27.7 percent) health. 
Retirement Probabilities by Health Status and Health Insurance Coverage

\begin{tabular}{|c|c|c|c|c|c|c|}
\hline & Excellent & $\begin{array}{l}\text { Very } \\
\text { Good }\end{array}$ & Good & Fair & Poor & $\begin{array}{l}\text { All } \\
\text { Types }\end{array}$ \\
\hline Percentage & 27.7 & 33.3 & 27.7 & 9.3 & 2.0 & \\
\hline \multicolumn{7}{|l|}{ Full retirement } \\
\hline $\begin{array}{l}\text { No insurance through } \\
\text { employer }\end{array}$ & 7.3 & 6.6 & 8.7 & 7.0 & 6.6 & 7.4 \\
\hline $\begin{array}{l}\text { Employer provided } \\
\text { health insurance }\end{array}$ & 8.2 & 8.2 & 8.3 & 9.0 & 6.7 & 8.2 \\
\hline $\begin{array}{l}\text { Any retiree health } \\
\text { insurance }\end{array}$ & 8.6 & 9.7 & 10.7 & 13.3 & 9.1 & 9.9 \\
\hline Insurance "locked" & 6.0 & 3.4 & 3.2 & 2.9 & 0.0 & 3.9 \\
\hline All workers & 7.9 & 7.7 & 8.4 & 8.1 & 6.7 & 8.0 \\
\hline Firm retirement & & & & & & \\
\hline $\begin{array}{l}\text { No insurance through } \\
\text { employer }\end{array}$ & 27.2 & 30.2 & 33.1 & 50.6 & 50.3 & 33.0 \\
\hline $\begin{array}{l}\text { Employer provided } \\
\text { health insurance }\end{array}$ & 19.6 & 21.2 & 20.2 & 25.7 & 40.6 & 21.2 \\
\hline $\begin{array}{l}\text { Any retiree health } \\
\text { insurance }\end{array}$ & 19.9 & 21.6 & 24.4 & 30.8 & 43.3 & 22.9 \\
\hline Insurance "locked" & 19.2 & 22.6 & 16.8 & 24.5 & 37.7 & 20.8 \\
\hline All workers & 22.1 & 24.2 & 24.7 & 37.3 & 44.3 & 25.3 \\
\hline
\end{tabular}

Notes: Each cell contains the probability that the employee retired from the labor force (full retirement) or left the Wave 1 employer (firm retirement) between the first two waves of the HRS. Probabilities are weighted by person-level weights. The sample includes all age-eligible respondents to the HRS Wave 1 for whom wealth and self-reported pension data are available in Wave 1 and whose labor force status could be obtained in Wave 2. Only respondents who are working but not self-employed are included.

The first two categories of insurance split the sample based on whether the worker receives health insurance coverage through her employer. For all health statuses, workers are more likely to leave their employers if they do not have employer-provided health insurance than if they do. However, the opposite is generally true for full retirement — probabilities are lower if there is no employer-provided health insurance. This difference suggests that the relationship for firm retirement is the result of other differences across jobs that are correlated with the availability of health insurance.

The next two categories relate to the availability of any form of retiree health insurance (whether through the employer or not). The third row tabulates retirement probabilities for workers with retiree health insurance. As in the case of employee health insurance, having retiree health insurance is associated with higher probabilities of full retirement and lower probabilities of firm retirement. The fourth row attempts to measure the extent to which health insurance coverage may be "locking" workers into their jobs. These workers have employer-provided health insurance but no retiree health insurance (from any source). For this group, both full and firm retirement probabilities are lower than average, especially for workers 
who are in very good or excellent health. It is clearly important to control for health insurance availability when analyzing retirement (e.g., see Gruber and Madrian 1996).

\subsection{The Distribution of Pension Wealth and Accruals}

We now turn to the distribution of pension wealth and accruals in the subsample of workers for whom detailed pension data are available. For workers who reported being covered by a pension in the first wave of the HRS, an attempt was made to contact the pension provider and obtain the summary plan description. Building on earlier work with the PPS for the 1983 SCF, the HRS staff has developed software to calculate pension entitlements based on the plan descriptions. The latest documentation of the software is Lamkin and Peticolas (1998). As noted above, calculating pension entitlements requires considerable precision in the household data. It also requires that the plan provisions be specified exactly.

Not all of the pensions are represented in the PPS. Approximately twothirds of the workers who reported having a pension in the HRS have their pensions in the PPS. For workers who reported a DB plan or DB and DC plans, the proportion of plans found is about 75 percent. For workers with DC only, the proportion is just over 50 percent. The difference is related to employer size. Defined benefit plans are disproportionately offered by large employers, both private and public. They are therefore easier to track down and more likely to have the relevant documents accessible to complete the survey. Our PPS sample includes 2,097 workers for whom we can calculate pension entitlements.

The proportion of workers whose self-reported pension types match the set of plans found in the PPS on their behalf is surprisingly low. The percentages getting the match exactly right are 60.10, 47.86, and 40.91 for the self-reported DB only, DC only, and DB-DC groups, respectively. Of particular concern are the 11.99 percent of the respondents who report DB only but actually have DC only, as well as the 28.16 percent who report DC only but actually have DB only. Such disparities illustrate why a comprehensive PPS is needed, but they also raise questions about whether workers should be expected to respond to the incentives they think they have or to the incentives they actually have. ${ }^{6}$ It is important to note that problems of misclassification are more likely to affect an HRS sample than the firmbased samples of Stock and Wise (1990a), since there is now a cross-section of plans in addition to people.

The derivation of the option value model of Stock and Wise (1990b) begins with an assumed indirect utility function:

6. See Gustman and Steinmeier (1999) for a comparison of the self-reported pension data and the PPS data in the HRS. 


$$
V_{t}(R)=\sum_{s=t}^{R-1} \beta^{s-t} \pi(s \mid t) E_{t}\left(y_{s}^{\gamma}\right)+\sum_{s=R}^{T} \beta^{s-t} \pi(s \mid t) E_{t}\left[k \cdot B_{s}(R)^{\gamma}\right]
$$

The variables and parameters in this equation are as follows:

$t$ : current age

$R$ : age of retirement

$T$ : maximum possible age

$\pi(s \mid t)$ : probability of surviving to age $s$ conditional on surviving to age $t$

$y_{s}:$ wages at age $s$

$B_{s}(R)$ : pension benefits at age $s$ conditional on retirement at age $R$

$\beta$ : discount factor (parameter)

$k$ : relative value of income during retirement (parameter)

$\gamma$ : risk aversion (parameter)

The first term in the expression on the right side is the indirect utility while working, and the second term is the indirect utility while retired. Stock and Wise (1990b) defined the option value of continued work to be $V_{t}\left(R^{*}\right)-V_{t}(t)$, where $R^{*}$ is the retirement age in $(t+1, \ldots, T)$ that maximizes that difference:

$$
\begin{aligned}
O V_{t}\left(R^{*}\right)= & \sum_{s=t}^{R^{*}-1} \beta^{s-t} \pi(s \mid t) E_{t}\left(y_{s}^{\gamma}\right)+\sum_{s=R^{*}}^{T} \beta^{s-t} \pi(s \mid t) E_{t}\left[k \cdot B_{s}\left(R^{*}\right)^{\gamma}\right] \\
& -\sum_{s=t}^{T} \beta^{s-t} \pi(s \mid t) E_{t}\left[k \cdot B_{s}(t)^{\gamma}\right]
\end{aligned}
$$

Stock and Wise (1990a) note that the probability that a worker retires at age $t$ is simply the probability that the option value is negative. They estimate the parameters of the model using maximum likelihood. In later work, Samwick (1998) specifies values for the utility function parameters to calculate the option value and includes that measure as an explanatory variable in a probit equation for retirement. In more recent work with the HRS, Coile and Gruber (1999a,b, 2000, 2001) and Coile (1999) use a variant of the option value that they call the "peak value" of retirement in similar reduced-form models:

$$
P K V_{t}\left(R^{*}\right)=\sum_{s=R^{*}}^{T} \beta^{s-t} \pi(s \mid t) E_{t}\left[B_{s}\left(R^{*}\right)\right]-\sum_{s=t}^{T} \beta^{s-t} \pi(s \mid t) E_{t}\left[B_{s}(t)\right]
$$

As discussed in Samwick (2001), the peak value is the same as the option value under the assumptions that future wages do not affect the optimal retirement age, workers are not risk averse $(\gamma=1)$, and income in retirement has the same utility value as income before retirement $(k=1)$. What these assumptions sacrifice in realism, they make up in analytical and computational convenience. The peak value is denominated in dollars, rather than measures of utility. The peak value chooses the retirement age that maximizes the value of the following measure, which we denote as the "multiyear accrual": 


$$
A C C_{t}(R)=\sum_{s=R}^{T} \beta^{s-t} \pi(s \mid t) E_{t}\left[B_{s}(R)\right]-\sum_{s=t}^{T} \beta^{s-t} \pi(s \mid t) E_{t}\left[B_{s}(t)\right]
$$

We use this measure directly in our reduced-form estimation. We vary the chosen retirement date over a range of possibilities. The importance of choosing a high value of $R$ is indicated by figure 8.2. The value of $\operatorname{ACC}_{50}(R)$ for $R$ less than 58 does not incorporate the large pension accrual that comes as a result of reaching thirty years of service and hence an earlier age for normal retirement. For illustrative purposes, we choose values of $R$ equal to $t+1, t+2,62$, and 65 in our empirical work. For horizons beyond a year, we scale the multiyear accrual by the length of the horizon (i.e., $R-t$ ) in order to have an annualized measure of pension accruals. Our economic assumptions include a 3 percent inflation rate, a 2 percent real interest rate (so that $\beta=1 /[1.03 \cdot 1.02]$ ), a 1 percent economywide wage increase, and a quadratic age-earnings profile around that aggregate such that nominal wage growth is 4.1 percent at age fifty and 3.2 percent at age seventy-five. Survival probabilities are given by the 1936 cohort life table.

Descriptive statistics for the pension and wage data are presented in table 8.6. The top panel is denominated in units of $\$ 10,000$. As a reference point, the mean wage in this sample is $\$ 35,100$, and the median is $\$ 31,000$. The next line shows the present value of pension benefits. The mean value of pension wealth is $\$ 129,800$, compared to a median of $\$ 58,300$. Pension

Table 8.6

Descriptive Statistics for Wage and Pension Variables

\begin{tabular}{|c|c|c|c|c|c|}
\hline & Mean & $\begin{array}{l}\text { Standard } \\
\text { Deviation }\end{array}$ & $\begin{array}{c}25 \text { th } \\
\text { Percentile }\end{array}$ & Median & $\begin{array}{c}75 \text { th } \\
\text { Percentile }\end{array}$ \\
\hline \multicolumn{6}{|c|}{ Pension and Wage Variables $(\$ 10,000 \mathrm{~s})$} \\
\hline Wage & 3.51 & 2.32 & 2.08 & 3.10 & 4.40 \\
\hline \multicolumn{6}{|l|}{ Pension variables } \\
\hline Present value & 12.98 & 20.38 & 1.44 & 5.83 & 17.01 \\
\hline Accrual, 1 year & 1.14 & 2.55 & 0.21 & 0.60 & 1.36 \\
\hline Accrual, 2 year & 1.13 & 1.80 & 0.24 & 0.64 & 1.45 \\
\hline Accrual, age 62 & 1.05 & 1.25 & 0.31 & 0.73 & 1.42 \\
\hline Accrual, age 65 & 0.92 & 1.07 & 0.32 & 0.66 & 1.22 \\
\hline \multicolumn{6}{|c|}{ Pension Variables as Ratios to Wages } \\
\hline Pension variables & & & & & \\
\hline Present value & 3.18 & 3.42 & 0.63 & 2.01 & 4.57 \\
\hline Accrual, 1 year & 0.30 & 0.50 & 0.09 & 0.20 & 0.37 \\
\hline Accrual, 2 year & 0.31 & 0.43 & 0.10 & 0.22 & 0.40 \\
\hline Accrual, age 62 & 0.29 & 0.25 & 0.14 & 0.26 & 0.39 \\
\hline Accrual, age 65 & 0.25 & 0.18 & 0.13 & 0.24 & 0.35 \\
\hline
\end{tabular}

Notes: The sample includes all age-eligible respondents to the HRS Wave 1 for whom wealth and self-reported pension data are available in Wave 1, whose labor force status could be obtained in Wave 2, who are working but not self-employed, and whose pension information is reported in the Pension Provider Survey (2,097 observations). Pension and wage variables are denominated in units of $\$ 10,000$, expressed in constant 1992 dollars. Ratios are to the wage level in the first wave of the survey. Accruals are annual averages over the specified horizon. 
wealth is more concentrated than wages, in large part because pension plans that cover higher-income workers tend to have higher replacement rates. The next four rows give the annualized values of the multiyear pension accruals defined above. Over the next year of the sample, the workers can expect pension wealth to increase by a mean of $\$ 11,400$ and a median of $\$ 6,000$. These numbers are sizable fractions of earnings. Over the next two years of the sample, the workers can expect pension wealth increments of $\$ 11,300$ at the mean and $\$ 6,400$ at the median in each year. Extending the horizon to age sixty-two increases the mean and median values to $\$ 10,500$ and $\$ 7,300$ per year.

During the age range when workers cannot retire and immediately begin collecting Social Security benefits, multiyear accruals decrease in mean and standard deviation and rise in median values. The reductions in the mean and standard deviation suggest that once a pension gives a large single-year accrual, it is less likely to offer another large accrual to the same worker. The increase in the median with the number of years indicates an increasing probability of having at least one large single-year accrual during the multiyear period. Further extending the horizon to age sixtyfive reduces both the mean and median values (to $\$ 9,200$ and $\$ 6,600$, respectively), suggesting that a large fraction of workers begin to see net reductions in pension wealth for delaying retirement until that age. The bottom panel of the table presents the distribution of pension wealth and accruals, normalized by the worker's wage. This normalization reduces the dispersion of the pension distribution, but it does not change the general pattern of increasing median multiyear accruals through age sixty-two, followed by a slight decline between ages sixty-two and sixty-five.

The HRS also allows for precise calculations of the analogous incentive measures for Social Security, as in Coile and Gruber (2001). These calculations are facilitated by a supplemental data set of Social Security earnings histories. We have not yet incorporated the earnings histories into our analysis. As a result, most of the variation in Social Security incentives is unavailable to us. The remaining variation in incentives is largely a function of age, marital status, and the wage in the survey year. At present, we control for those factors directly in our econometric estimates.

\subsection{Reduced Form Estimates}

In this section, we estimate reduced form models of the effect of pension wealth and accruals on the probability of retirement using a probit specification. We include the level of pension wealth, the accrual of pension wealth, and the wage to capture the main features of the worker's budget constraint. We use each of the four accrual measures summarized in table 8.6 in separate equations. We also control for a number of other potentially important factors: net worth, health status, health insurance, union status, 
gender, marital status, education, and age. The key predictions to be tested are for a positive effect of pension wealth on the probability of retirement and a negative effect of the pension wealth accrual and the wage on the probability of retirement.

Table 8.7 reports the results using full retirement as the dependent variable. The coefficients from the probit have been transformed into the marginal effects of the variables, evaluated at the sample means of the independent variables. ${ }^{7}$ The four columns correspond to different horizons for the pension accrual variable, with the one-year accrual in the first column and the average multiyear accrual to age sixty-five in the fourth column. The estimates for variables other than the pension and wage variables do not change in a substantive way as the horizon on the retirement incentives variable is increased.

The results on the key variables are mixed in this set of estimates. The present value of pension wealth is positive and significant in every specification, as predicted. Using the fourth column, an increase of $\$ 100,000$ in pension wealth (about one-half of a standard deviation) would increase the probability of retirement by 1.9 percentage points. This increase represents 18 percent of the baseline probability of full retirement of 10.54 percentage points. ${ }^{8}$ The pension accrual is positive and insignificant in the specifications that use one or two years as the horizon. It has a negative effect when measured over longer horizons. In the fourth column, it is statistically significant. The point estimate for the marginal effect is -0.0198 , suggesting that a $\$ 10,000$ increase in the average accrual (roughly one standard deviation) would reduce the probability of full retirement over the two-year interval between the waves of the survey by 1.98 percentage points, or 19 percent of the baseline retirement probability.

Based on the examples in figures 8.1 and 8.2, it is not surprising that measures of pension accruals that incorporate more years are more significantly related to retirement. Another insight as to the difference between the pension accrual measures is reflected in the marginal effects for the wage. The wage is estimated to have a negative effect in all specifications, as predicted. The effect is on the order of -0.01 , with larger and more significant results occurring for the shorter horizon measures. This pattern is consistent with the extra information in the longer horizon relative to the one-year horizon being correlated with the wage, and this accounts for the changes in the marginal effects with the horizon length.

The effects of the other control variables are consistent with the crosstabulations presented in tables 8.3 through 8.5 . Higher net worth is associ-

7. For dummy variables, the marginal effect is evaluated as the difference in the probabilities when the dummy equals 1 compared to 0 .

8. This differs from the probability of 8 percent in table 8.3 because the sample here includes only those workers with pensions in the PPS. For firm retirement, the baseline probability of retirement is 18.93 percent, compared to 25.3 percent in table 8.4. 


\begin{tabular}{|c|c|c|c|c|}
\hline & \multicolumn{4}{|c|}{ Accrual Period for Pension Incentives } \\
\hline & One Year & Two Year & Until Age 62 & Until Age 65 \\
\hline \multirow[t]{2}{*}{ Pension present value } & 0.0017 & 0.0017 & 0.0019 & 0.0019 \\
\hline & $(0.0004)$ & $(0.0004)$ & $(0.0004)$ & $(0.0004)$ \\
\hline \multirow[t]{2}{*}{ Pension accrual } & 0.0021 & 0.0020 & -0.0093 & -0.0198 \\
\hline & $(0.0022)$ & $(0.0039)$ & $(0.0074)$ & $(0.0081)$ \\
\hline \multirow[t]{2}{*}{ Wage } & -0.0098 & -0.0096 & -0.0057 & -0.0024 \\
\hline & $(0.0045)$ & $(0.0044)$ & $(0.0043)$ & $(0.0055)$ \\
\hline \multirow[t]{2}{*}{ Net worth 2nd quartile } & 0.0234 & 0.0234 & 0.0225 & 0.0211 \\
\hline & $(0.0208)$ & $(0.0208)$ & $(0.0207)$ & $(0.0205)$ \\
\hline \multirow[t]{2}{*}{ Net worth 3rd quartile } & 0.0728 & 0.0733 & 0.0729 & 0.0703 \\
\hline & $(0.0259)$ & $(0.0259)$ & $(0.0258)$ & $(0.0256)$ \\
\hline \multirow[t]{2}{*}{ Net worth 4th quartile } & 0.1214 & 0.1214 & 0.1213 & 0.1200 \\
\hline & $((0.0310)$ & $(0.0310)$ & $(0.0308)$ & $(0.0306)$ \\
\hline \multirow[t]{2}{*}{ Health status very good } & 0.0104 & 0.0105 & 0.0104 & 0.0096 \\
\hline & $(0.0148)$ & $(0.0148)$ & $(0.0148)$ & $(0.0147)$ \\
\hline \multirow[t]{2}{*}{ Health status good } & 0.0220 & 0.0226 & 0.0224 & 0.0209 \\
\hline & $(0.0167)$ & $(0.0167)$ & $(0.0167)$ & $(0.0165)$ \\
\hline \multirow[t]{2}{*}{ Health status fair } & 0.0710 & 0.0709 & 0.0701 & 0.0695 \\
\hline & $(0.0324)$ & $(0.0324)$ & $(0.0322)$ & $(0.0320)$ \\
\hline \multirow[t]{2}{*}{ Health status poor } & -0.0082 & -0.0071 & -0.0074 & -0.0089 \\
\hline & $(0.0494)$ & $(0.0507)$ & $(0.0516)$ & $(0.0507)$ \\
\hline \multirow[t]{2}{*}{ Health insurance own employer } & -0.0085 & -0.0081 & -0.0087 & -0.0107 \\
\hline & $(0.0171)$ & $(0.0170)$ & $(0.0171)$ & $(0.0173)$ \\
\hline \multirow[t]{2}{*}{ Health insurance any retiree } & 0.0344 & 0.0347 & 0.0352 & 0.0355 \\
\hline & $(0.0200)$ & $(0.0200)$ & $(0.0199)$ & $(0.0197)$ \\
\hline \multirow[t]{2}{*}{ Health insurance "locked" } & -0.0209 & -0.0209 & -0.0231 & -0.0232 \\
\hline & $(0.0254)$ & $(0.0254)$ & $(0.0248)$ & $(0.0247)$ \\
\hline \multirow[t]{2}{*}{ Union member } & 0.0487 & 0.0491 & 0.0492 & 0.0479 \\
\hline & $(0.0122)$ & $(0.0123)$ & $(0.0123)$ & $(0.0123)$ \\
\hline \multirow[t]{2}{*}{ Male } & 0.0369 & 0.0368 & 0.0344 & 0.0307 \\
\hline & $(0.0230)$ & $(0.0230)$ & $(0.0229)$ & $(0.0229)$ \\
\hline \multirow[t]{2}{*}{ Married } & -0.0169 & -0.0168 & -0.0179 & -0.0192 \\
\hline & $(0.0213)$ & $(0.0213)$ & $(0.0214)$ & $(0.0215)$ \\
\hline \multirow[t]{2}{*}{ Married male } & -0.0358 & -0.0359 & -0.0364 & -0.0353 \\
\hline & $(0.0268)$ & $(0.0268)$ & $(0.0268)$ & $(0.0268)$ \\
\hline \multirow[t]{2}{*}{ High school diploma } & 0.0074 & 0.0073 & 0.0068 & 0.0071 \\
\hline & $(0.0139)$ & $(0.0139)$ & $(0.0138)$ & $(0.0137)$ \\
\hline \multirow[t]{2}{*}{ College degree } & 0.0072 & 0.0073 & 0.0056 & 0.0041 \\
\hline & $(0.0175)$ & $(0.0175)$ & $(0.0171)$ & $(0.0215)$ \\
\hline \multirow[t]{2}{*}{ Advanced degree } & -0.0033 & -0.0038 & -0.0050 & -0.0065 \\
\hline & $(0.0190)$ & $(0.0189)$ & $(0.0187)$ & $(0.0186)$ \\
\hline Log-likelihood & -590.7896 & -591.1238 & -589.9275 & -586.7828 \\
\hline
\end{tabular}

Notes: Each cell contains the marginal effect on the probability that the employee retired from the labor force (full retirement) between the first two waves of the HRS. Standard errors are reported in parentheses beneath each coefficient. The sample includes all age-eligible respondents to the HRS Wave 1 for whom wealth and self-reported pension data are available in Wave 1, whose labor force status could be obtained in Wave 2, who are working but not selfemployed, and whose pension information is reported in the Pension Provider Survey (2102 observations). Column headings indicate the type of pension accrual variable that is used. Dummy variables for each sample age are included, but coefficients are not reported. 
ated with greater probabilities of full retirement. The effect at the highest quartile is particularly strong: Moving from the 3 rd to the 4th quartile increases the probability of retirement by 5 percentage points. Worse health status is also associated with greater probabilities of full retirement in moving from excellent to fair health. Moving from good to fair health increases the retirement probability by about 5 percentage points. Moving from fair to poor health does not increase the probability of full retirement, because other exits from working, such as disability, compete with retirement. Having retirement health insurance available increases the probability of retirement by 3.5 percentage points. The coefficients on having insurance through the employer and "locked" into health insurance are negative but insignificant. Unionized workers are more likely to retire. Gender, marital status, and education levels are not statistically significant.

Table 8.8 presents the same specifications as table 8.7, but with firm retirement as the dependent variable. The same patterns emerge as in the previous table, with more significant results on both pension wealth and pension accruals. This is not surprising, as pension incentives apply directly to departures from the firm, even those that do not include full retirement. The marginal effect of pension wealth in the age sixty-five specification is 2.4 percentage points per $\$ 100,000$. This reflects 12.68 percent of the baseline probability of 18.93 in this sample. A $\$ 10,000$ increase in average pension accruals would generate firm retirement probabilities that were 3.30 percentage points lower, or 17.43 percent of the baseline probability of firm retirement.

\subsection{Conclusion}

Our analysis shows that financial incentives in employer-provided pension plans have important effects on retirement behavior. As a prelude to more structural modeling of retirement, we use a non-utility-based measure of the financial incentives to delay retirement that is similar to the option value of Stock and Wise (1990b) and the peak value of Coile and Gruber $(2000,2001)$. We show that when the financial incentives are calculated over a sufficiently long period, higher financial incentives to delay retirement predict lower retirement rates. Pensions have a far more robust effect on the decision to leave a particular firm than they do on the decision to leave the labor force entirely, as they do not condition benefit receipt on anything other than separating with the firm. This is in contrast to Social Security, which does not distinguish between the firms at which wages were earned but does condition benefit receipt on, for example, labor market earnings and adjusted gross income.

In contrast to past studies, (e.g., Samwick 1998) we find an important wealth effect of the present value of pension benefits on the decision to retire. This is mirrored in a strong effect of nonpension wealth on retirement, 


\begin{tabular}{|c|c|c|c|c|}
\hline & \multicolumn{4}{|c|}{ Accrual Period for Pension Incentives } \\
\hline & One Year & Two Year & Until Age 62 & Until Age 65 \\
\hline \multirow[t]{2}{*}{ Pension present value } & 0.0020 & 0.0020 & 0.0023 & 0.0024 \\
\hline & $(0.0006)$ & $(0.0006)$ & $(0.0006)$ & $(0.0007)$ \\
\hline \multirow[t]{2}{*}{ Pension accrual } & -0.0007 & -0.0024 & -0.0214 & -0.0330 \\
\hline & $(0.0042)$ & $(0.0067)$ & $(0.0108)$ & $(0.0123)$ \\
\hline \multirow[t]{2}{*}{ Wage } & -0.0125 & -0.0121 & -0.0062 & -0.0031 \\
\hline & $(0.0061)$ & $(0.0061)$ & $(0.0064)$ & $(0.0066)$ \\
\hline \multirow[t]{2}{*}{ Net worth 2nd quartile } & 0.0024 & 0.0025 & 0.0013 & 0.0004 \\
\hline & $(0.0261)$ & $(0.0261)$ & $(0.0260)$ & $(0.0260)$ \\
\hline \multirow[t]{2}{*}{ Net worth 3rd quartile } & 0.0379 & 0.0381 & 0.0363 & 0.0343 \\
\hline & $(0.0284)$ & $(0.0284)$ & $(0.0282)$ & $(0.0282)$ \\
\hline \multirow[t]{2}{*}{ Net worth 4th quartile } & 0.1227 & 0.1229 & 0.1223 & 0.1222 \\
\hline & $(0.0335)$ & $(0.0335)$ & $(0.0334)$ & $(0.0334)$ \\
\hline \multirow[t]{2}{*}{ Health status very good } & 0.0355 & 0.0356 & 0.0349 & 0.0345 \\
\hline & $(0.0234)$ & $(0.0234)$ & $(0.0234)$ & $(0.0234)$ \\
\hline \multirow[t]{2}{*}{ Health status good } & 0.0436 & 0.0436 & 0.0429 & 0.0416 \\
\hline & $(0.0251)$ & $(0.0250)$ & $(0.0250)$ & $(0.0250)$ \\
\hline \multirow[t]{2}{*}{ Health status fair } & 0.1345 & 0.1347 & 0.1328 & 0.1329 \\
\hline & $(0.0425)$ & $(0.0425)$ & $(0.0423)$ & $(0.0423)$ \\
\hline \multirow[t]{2}{*}{ Health status poor } & 0.2947 & 0.2951 & 0.2936 & 0.2918 \\
\hline & $(0.1064)$ & $(0.1065)$ & $(0.1064)$ & $(0.1062)$ \\
\hline \multirow[t]{2}{*}{ Health insurance own employer } & -0.0318 & -0.0319 & -0.0333 & -0.0358 \\
\hline & $(0.0269)$ & $(0.0269)$ & $(0.0270)$ & $(0.0271)$ \\
\hline \multirow[t]{2}{*}{ Health insurance any retiree } & -0.0156 & -0.0157 & -0.0136 & -0.0127 \\
\hline & $(0.0360)$ & $(0.0359)$ & $(0.0358)$ & $(0.0356)$ \\
\hline \multirow[t]{2}{*}{ Health insurance "locked" } & -0.0321 & -0.0325 & -0.0335 & -0.0314 \\
\hline & $(0.0388)$ & $(0.0387)$ & $(0.0386)$ & $(0.0387)$ \\
\hline \multirow[t]{2}{*}{ Union member } & 0.0230 & 0.0234 & 0.0225 & 0.0211 \\
\hline & $(0.0176)$ & $(0.0176)$ & $(0.0175)$ & $(0.0175)$ \\
\hline \multirow[t]{2}{*}{ Male } & 0.0253 & 0.0250 & 0.0226 & 0.0194 \\
\hline & $(0.0363)$ & $(0.0363)$ & $(0.0364)$ & $(0.0364)$ \\
\hline \multirow[t]{2}{*}{ Married } & -0.0719 & -0.0720 & -0.0734 & -0.0747 \\
\hline & $(0.0329)$ & $(0.0329)$ & $(0.0329)$ & $(0.0330)$ \\
\hline \multirow[t]{2}{*}{ Married male } & -0.0112 & -0.0111 & -0.0128 & -0.0117 \\
\hline & $(0.0420)$ & $(0.0420)$ & $(0.0420)$ & $(0.0420)$ \\
\hline \multirow[t]{2}{*}{ High school diploma } & 0.0446 & 0.0445 & 0.0439 & 0.0446 \\
\hline & $(0.0216)$ & $(0.0216)$ & $(0.0216)$ & $(0.0216)$ \\
\hline \multirow[t]{2}{*}{ College degree } & 0.0319 & 0.0318 & 0.0312 & 0.0309 \\
\hline & $(0.0272)$ & $(0.0272)$ & $(0.0271)$ & $(0.0271)$ \\
\hline \multirow[t]{2}{*}{ Advanced degree } & -0.0713 & -0.0711 & -0.0730 & -0.7042 \\
\hline & $(0.0245)$ & $(0.0245)$ & $(0.0244)$ & $(0.0243)$ \\
\hline Log-likelihood & -943.4425 & -943.3694 & -941.0250 & -939.4280 \\
\hline
\end{tabular}

Notes: Each cell contains the marginal effect on the probability that the employee left the Wave 1 employer (firm retirement) between the first two waves of the HRS. Standard errors are reported in parentheses beneath each coefficient. The sample includes all age-eligible respondents to the HRS Wave 1 for whom wealth and self-reported pension data are available in Wave 1, whose labor force status could be obtained in Wave 2, who are working but not selfemployed, and whose pension information is reported in the Pension Provider Survey (2102 observations). Column headings indicate the type of pension accrual variable that is used. Dummy variables for each sample age are included, but coefficients are not reported. 
especially in the distinction between the top quartile and the rest of the wealth distribution. As expected, there is also a strong effect of health status on retirement probabilities, particularly for the roughly 10 percent of the sample reporting fair or poor health.

Our current analysis suggests several areas for future research. First, the measures of retirement incentives can be expanded to include Social Security wealth and accruals, making full use of the Social Security earnings histories that are available with the HRS. Second, the sample can be extended to include subsequent waves of the survey to observe additional retirements and postretirement behavior. Third, the structural parameters of the option value model can be estimated. Fourth, the effects of wealth, health, and other job characteristics can be integrated more formally into the calculation and estimation of the option value of retirement.

\section{References}

Ausink, J. 1991. The effect of changes in compensation on a pilot's decision to leave the air force. Ph.D. Diss. Harvard University, John F. Kennedy School of Government, Cambridge, Mass.

Ausink, J., and D. Wise. 1996. The military pension, compensation, and retirement of U.S. Air Force pilots. In Advances in the Economics of Aging, ed. D. Wise, 83109. Chicago: University of Chicago Press.

Bulow, J. 1981. Early retirement pension benefits. NBER Working Paper no. 654. Cambridge, Mass.: National Bureau of Economic Research, April.

Coile, C. 1999. Social security, pensions, and the retirement decisions of couples. MIT, Department of Economics.

Coile, C., and J. Gruber. 2000. Social security and retirement. NBER Working Paper no. 7830. Cambridge, Mass.: National Bureau of Economic Research, August.

Coile, C., and J. Gruber. 2001. Social security incentives for retirement. In Themes in the Economics of Aging, ed. D. Wise, 311-341. Chicago: University of Chicago Press.

Gruber, J., and B. Madrian. 1996. Health insurance and early retirement: Evidence from the availability of continuation coverage. In Advances in the Economics of Aging, ed. D. Wise, 115-43. Chicago: University of Chicago Press.

Gruber, J., and D. Wise. 1998. Introduction and summary of papers. In Social security programs and retirement around the world, ed. J. Gruber and D. Wise, 1-35. Chicago: University of Chicago Press.

Gustman, A., and T. Steinmeier. 1999. Effects of pensions on saving: Analysis with data from the Health and Retirement Study. Carnegie-Rochester Conference Series 50 (July): 271-326.

Harris, A. 2001. The effects of social security on retirement behavior: A test of the option-value model using the Health and Retirement Study. Congressional Budget Office, Manuscript, February.

Kotlikoff, L., and D. Wise. 1985. Labor compensation and the structure of private pension plans: Evidence for contractual versus spot labor markets. In Pensions, labor, and individual choice, ed. D. Wise. Chicago: University of Chicago Press. 
1987. The incentive effects of private pension plans. In Issues in Pension Economics, ed. Z. Bodie, J. Shoven, and D. Wise, 283-336. Chicago: University of Chicago Press.

. 1989a. Employee retirement and a firm's pension plan. In Economics of Aging, ed. D. Wise, 279-330. Chicago: University of Chicago Press.

. 1989b. The wage carrot and the pension stick: Retirement benefits and labor force participation. Upjohn Institute for Employment Research.

Lamkin, J., and B. Peticolas. 1998. Pension estimation program documentation (Richard Curtin): Modified for use with PCs. University of Michigan, Survey Research Center. Mimeograph.

Lazear, E. 1983. Pensions as severance pay. In Financial Aspects of the United States Pension System, ed. Z. Bodie and J. Shoven, 57-85. Chicago: University of Chicago Press.

Lumsdaine, R., J. Stock, and D. Wise. 1990. Efficient windows and labor force reduction. Journal of Public Economics 43 (2): 131-59. 1991. Fenêtres et retraites (Windows and retirement), Annales d'Economie et de Statistique 20/21:219-42.

1992. Three models of retirement: Computational complexity versus predictive validity. In Topics in the economics of aging, ed. D. Wise, 21-60. Chicago: University of Chicago Press.

- 1993. Pension plan provisions and retirement: Men \& women, Medicare, and models. In The economics of aging, ed. D. Wise, 183-212. Chicago: University of Chicago Press.

Ruhm, C. 1990. Bridge jobs and partial retirement. Journal of Labor Economics $8: 482-501$.

Samwick, A. 1998. New evidence on pensions, social security, and the timing of retirement. Journal of Public Economics 70:207-36.

- 2001. Comment on Coile and Gruber: Social security incentives for retirement. In Themes in the Economics of Aging, ed. D. Wise, 341-54. Chicago: University of Chicago Press.

Stock, J., and D. Wise. 1990a. The pension inducement to retire: An option value analysis. In Issues in the Economics of Aging, ed. D. Wise, 205-24. Chicago: University of Chicago Press.

. 1990b. Pensions, the option value of work, and retirement. Econometrica 58 (5): 1151-80. 